\title{
Integrated Status and Effectiveness Monitoring Program -Entiat River Snorkel Surveys and Rotary Screw Trap, 2007.
}

July 2007- January 2008

\author{
Prepared by: \\ R.D. Nelle \\ Michael Cotter \\ Matt Cooper \\ Fish Biologists \\ U.S. Fish and Wildlife Service \\ Mid-Columbia River Fishery Resource Office \\ 7501 Icicle Rd. \\ Leavenworth WA 98826
}

Funded by

U.S. Department of Energy

Bonneville Power Administration

Division of Fish and Wildlife

Portland, OR. 97208-3621

Project No. 2003-017-00

Contract No. 28029 


\section{Table of Contents}

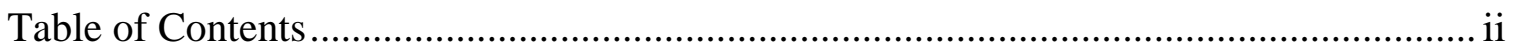

List of Tables ........................................................................................................ ii

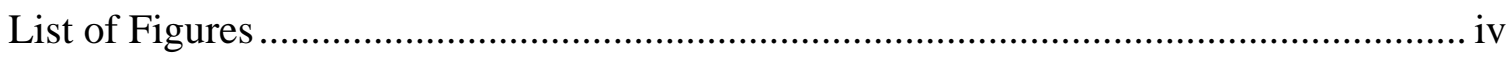

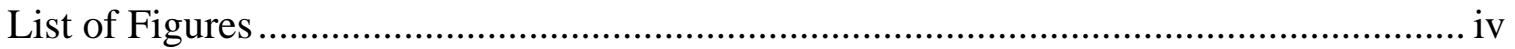

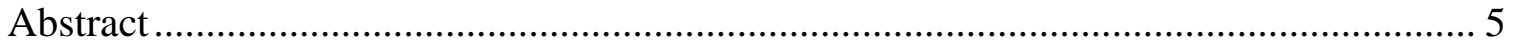

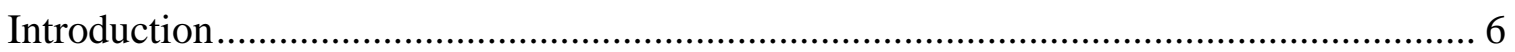

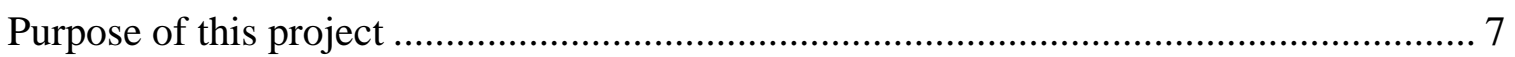

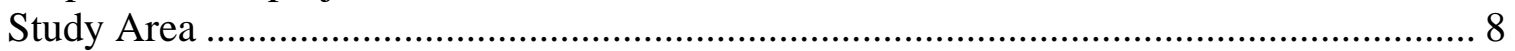

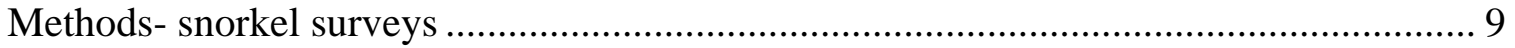

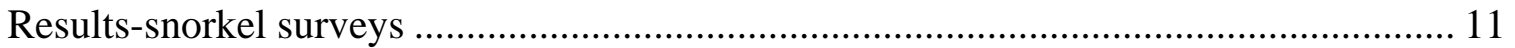

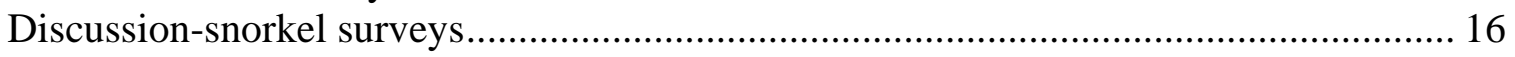

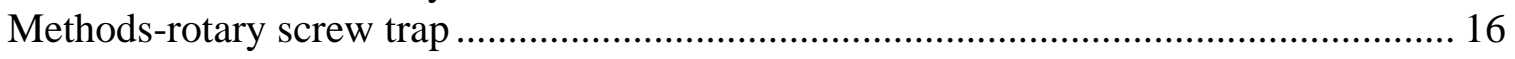

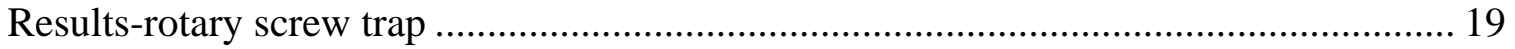

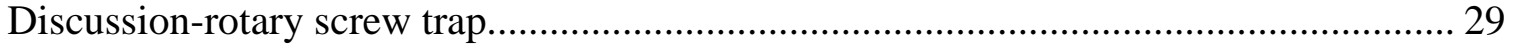

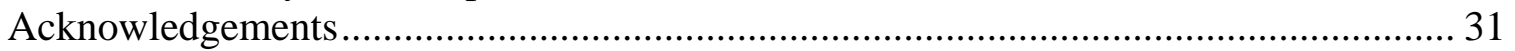

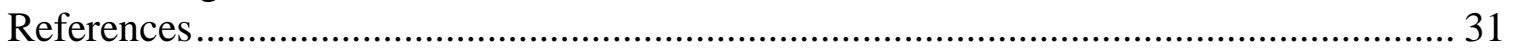




\section{List of Tables}

Table 1. Experimental site descriptions and locations snorkeled in the Entiat River during the sample period from August to October 2007.

Table 2. Water quality measurements for sites and times snorkeled in the Entiat River during 2007. Mean discharge data is from USGS gage site number $12452990 \ldots . . . .13$

Table 3. The number of fish species observed by period and time of day during snorkel surveys in the Entiat River during August and October 2007.............................. 15

Table 4. Rotary screw trap operation time from August through November 2007......... 20 Table 5. Juvenile salmonid catch and PIT tag totals from Entiat River rotary screw traps.

Table 6. Remote PIT tag summary data from August through November 2007............. 26

Table 7. Rotary screw trap efficiency trials August through November 2007. Wild Chinook denoted as CHN and steelhead/rainbow trout as SRT........................... 28 


\section{List of Figures}

Figure 1. Study reach map of the Entiat River watershed with the juvenile rotary screw trap locations.

Figure 2. Study reach map of the Entiat River watershed with snorkel survey area from Rkm 0.5 to 34.4

Figure 3. Daily mean discharge $\left(\mathrm{ft}^{3} / \mathrm{sec}\right)$ for the period from July 1, 2007 to December 1 , 2007 for USGS gage station 12452990 at Rkm 2.3 in the Entiat River.

Figure 4. Length frequency distribution of wild Chinook captured from Entiat River rotary screw traps August 2007.

Figure 5. Length frequency distribution of wild steelhead captured from Entiat River rotary screw traps August 2007.

Figure 6. Length frequency distribution of wild Chinook captured from Entiat River rotary screw traps September 2007

Figure 7. Length frequency distribution of wild steelhead captured from Entiat River rotary screw traps September 2007.

Figure 8. Length frequency distribution of wild Chinook captured from Entiat River rotary screw traps October 2007.

Figure 9. Length frequency distribution of wild steelhead captured from Entiat River rotary screw traps October 2007.

Figure 10. Length frequency distribution of wild Chinook captured from Entiat River rotary screw traps November 2007.

Figure 11. Length frequency distribution of wild steelhead captured from Entiat River rotary screw traps November 2007.

Figure 12. Juvenile salmonid rotary screw trap catch and daily average water temperature (dashed line) August through November 2007.

Figure 13. Juvenile salmonid rotary screw trap catch and daily discharge (dashed line) from the Entiat River August through November 2007. 27 


\begin{abstract}
The USFWS Mid-Columbia River Fishery Resource Office conducted snorkel surveys at 24 sites during the summer and fall periods of 2006 survey periods as part of the Integrated Status and Effectiveness Monitoring Program in the Entiat River. A total of 37,938 fish from 15 species/genera and an unknown category were enumerated. Chinook salmon were the overall most common fish observed and comprised $15 \%$ of fish enumerated followed by rainbow trout (10\%) and mountain whitefish (7\%). Day surveys were conducted during the summer period 2007 (August), while night surveys were conducted during the fall 2007 (October) surveys. The USFWS Mid-Columbia River Fishery Resource Office (MCFRO) operated two rotary screw traps on the Entiat River as part of the Integrated Status and Effectiveness Monitoring Program (ISEMP) program from August through November of 2007. Along with the smolt traps, juvenile emigrants were also captured at remote locations throughout the Entiat watershed and its major tributary, the Mad River. A total of 999 wild Oncorhynchus mykiss and 5,107 wild run $O$. tshawytscha were PIT tagged during the study period. Rotary screw trap efficiencies averaged 22.3\% for juvenile O. tshawytscha and 9.0\% for juvenile O. mykiss. Rotary screw traps operated 7 days a week and remote capture operations were conducted when flow and temperature regimes permitted.
\end{abstract}




\section{Introduction}

The Integrated Status and Effectiveness Monitoring Program (ISEMP - BPA project \#2003-0017) has been created as a cost effective means of developing protocols and new technologies, novel indicators, sample designs, analytical, data management and communication tools and skills, and restoration experiments that support the development of a region-wide Research, Monitoring and Evaluation (RME) program to assess the status of anadromous salmonid populations, their tributary habitat and restoration and management actions.

The most straightforward approach to developing a regional-scale monitoring and evaluation program would be to increase standardization among status and trend monitoring programs. However, the diversity of species and their habitat, as well as the overwhelming uncertainty surrounding indicators, metrics, and data interpretation methods, requires the testing of multiple approaches. Thus, the approach ISEMP has adopted is to develop a broad template that may differ in the details among subbasins, but one that will ultimately lead to the formation of a unified RME process for the management of anadromous salmonid populations and habitat across the Columbia River Basin.

ISEMP has been initiated in three pilot subbasins, the Wenatchee/Entiat, John Day, and Salmon. To balance replicating experimental approaches with the goal of developing monitoring and evaluation tools that apply as broadly as possible across the Pacific Northwest, these subbasins were chosen as representative of a wide range of potential challenges and conditions, e.g., differing fish species composition and life histories, ecoregions, institutional settings, and existing data.

ISEMP has constructed a framework that builds on current status and trend monitoring infrastructures in these pilot subbasins, but challenges current programs by testing alternative monitoring approaches. In addition, the ISEMP is:

1) Collecting information over a hierarchy of spatial scales, allowing for a greater flexibility of data aggregation for multi-scale recovery planning assessments, and

2) Designing methods that:

a) Identify factors limiting fish production in watersheds;

b) Determine restoration actions to address these problems;

c) Implement actions as a large-scale experiment (e.g. Before After Control Impact, or BACI design), and

d) Implement intensive monitoring and research to evaluate the action's success.

The intent of the ISEMP project is to design monitoring programs that can efficiently collect information to address multiple management objectives over a broad range of scales. This includes:

- Evaluating the status of anadromous salmonids and their habitat;

- Identifying opportunities to restore habitat function and fish performance, and 
- Evaluating the benefits of the actions to the fish populations across the Columbia River Basin.

The multi-scale nature of this goal requires the standardization of protocols and sampling designs that are statistically valid and powerful, properties that are currently inconsistent across the multiple monitoring programs in the region. Other aspects of the program will aid in the ability to extrapolate information beyond the study area, such as research to elucidate causal mechanisms, and a classification of watersheds throughout the Columbia River Basin. Obviously, the scale of the problem is immense and the ISEMP does not claim to be the only program working towards this goal. As such, ISEMP relies heavily on the basin's current monitoring infrastructure to test and develop monitoring strategies, while acting as a coordinating body and providing support for key elements such as data management and technical analyses. The ISEMP also ensures that monitoring programs can address large-scale management objectives (resulting largely from the ESA) through these local efforts. While the ISEMP maintains a regional focus it also returns the necessary information to aid in management at the smaller spatial scales (individual projects) where manipulations (e.g., habitat restoration actions) actually occur.

The work captured in this report is a component of the overall Integrated Status and Effectiveness Monitoring Program, and while it stands alone as an important contribution to the management of anadromous salmonids and their habitat, it also plays a key role within ISEMP. Each component of work within ISEMP is reported on individually, as is done so here, and in annual and triennial summary reports that present all of the overall project components in their programmatic context and shows how the data and tools developed can be applied to the development of regionally consistent, efficient and effective Research, Monitoring and Evaluation.

Snorkel surveys

\section{Purpose of this project}

This is third annual progress report to Bonneville Power Administration for the snorkel surveys conducted in the Entiat River as related to long-term effectiveness monitoring of restoration programs in this watershed.

In 2005, the Cascadia Conservation District (CCD) in association with the Entiat Watershed Planning Unit (EWPU) initiated a large-scale restoration program in a $2000 \mathrm{~m}$ section of the Entiat River watershed, known as the "Entiat Bridge-to-Bridge Project". This is a phased program that will, over a several year period, incorporate a suite of stream restoration measures that include in-stream habitat structures, the reconnection of relict stream channels, and riparian plantings. This project has since grown to include the Entiat River downstream of the Entiat National Fish Hatchery at Rkm 10.9. The restoration efforts in the Entiat River are intended to provide complexity to the river system and a positive benefit for aquatic organisms including ESA listed fish species.

The Entiat River Effectiveness Monitoring Study plans to evaluate fish utilization of instream habitat modifications within the Entiat River. The U.S. Fish and Wildlife Service's Mid-Columbia River Fishery Resource Office (MCRFRO) is conducting the snorkeling component of the Entiat Effectiveness Monitoring Study that will evaluate fish habitat utilization associated with in-stream restoration work planned for the lower Entiat River. 
The objective of this study is to monitor the fish habitat utilization of planned in-stream restoration efforts in the Entiat River by conducting pre- and post-construction snorkel surveys at selected treatment and control sites.

Juvenile outmigation study

The primary goal of this study is to provide long-term monitoring information about the juvenile life history characteristics and productivity of ESA listed spring Chinook salmon and steelhead in the Entiat River basin. Specifically, the study primarily utilizes migrant traps and to some extent seines and angling to capture juveniles in order to quantify abundance, measure physical characteristics, and tag individuals to assess migration timing and survival. Once obtained this data is incorporated into a regional database that is utilized by area resource managers to compare attributes both within and among populations located in the Upper Columbia River basin. The final outcome of this study is to guide scientifically sound decisions regarding the future management of these imperiled species.

This document reports the data collected from juvenile collection operations from August 1 through November $20^{\text {th }} 2007$.

\section{Study Area}

The Entiat River watershed originates from 11 glaciers and snowfields in the Cascade Mountains and flows southeast approximately $69 \mathrm{~km}$ to join the Columbia River at river kilometer (Rkm) 778 (CCCD 2004, Mullan et al. 1992). The Entiat watershed is bordered by the Entiat Mountains to the southwest and the Chelan Mountains to the northeast and drains approximately $1,085 \mathrm{~km}^{2}$. The topography is steep with unstable erodible soils and vegetation types varying from semi-arid shrub steppe near the confluence with the Columbia River to temperate forests and alpine meadows in the headwaters.

Past glacial activity has shaped the Entiat River valley by creating a U-shaped valley upstream of terminal moraine at Rkm 26.1 and V shaped valley downstream (Mullan et al. 1992). The present upstream limit to anadromy is at Entiat Falls Rkm 54.4.

The Mid-Columbia River Fishery Resource Office (MCRFRO) has been operating a rotary screw trap in the Entiat River at river kilometer $(\mathrm{Rkm}) 11$ adjacent to the Entiat National Fish Hatchery (ENFH) since 2003, and has captured juvenile fish at other sites within the Entiat Basin for PIT tagging since 2005. In addition to the legacy collection sites, the MCRFRO added another rotary screw trap at Rkm 2 for the 2007 field season (Figure 1).

The snorkel survey study reach is located in Entiat River between the Rkm 0.5 to 34.4 and the Bridge to Bridge section is located between Rkm 5.2 to 7.4 (Figure 2).

The Entiat River watershed supports seven native and one introduced salmonid species which include, spring and summer Chinook salmon Oncorhynchus tshawytscha, steelhead and resident rainbow trout $O$. mykiss gairdneri, sockeye salmon O. nerka, 


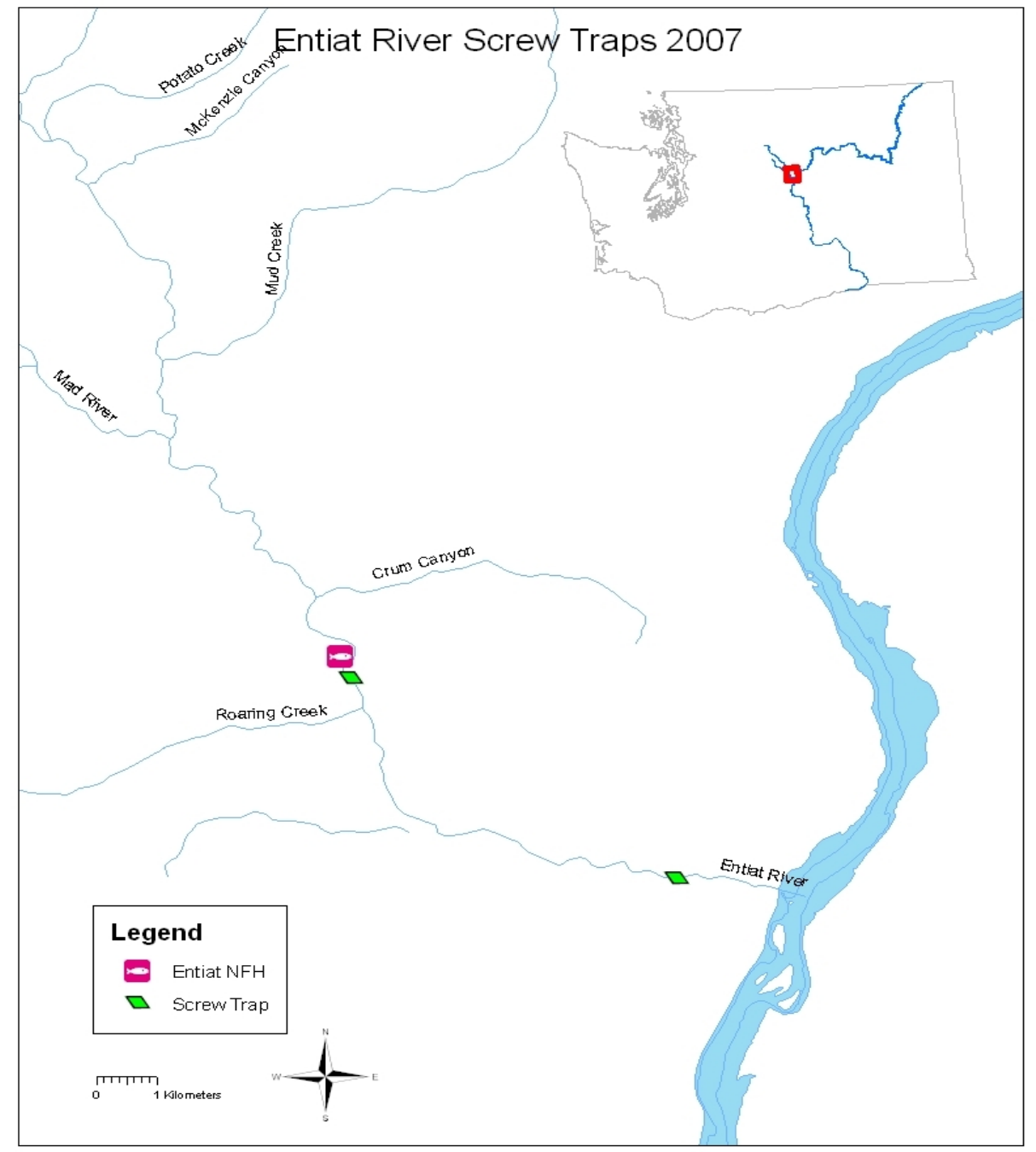

Figure 1. Study reach map of the Entiat River watershed with the juvenile rotary screw trap locations.

westslope cutthroat trout O. clarki lewisi, coho salmon O. kisutch, mountain whitefish Prosopium williamsoni, bull trout Salvelinus confluentus, and introduced eastern brook trout $S$. fontinalis. Other fish species include, chiselmouth Acrocheilus alutaceus, northern pikeminnow Ptychocheilus oregonensis, largescale sucker Catostomus macrocheilus, bridgelip sucker $C$. columbianus, speckled dace Rhinichthys osculus, longnose dace $R$. cataractae, redside shiner Richardsonius balteatus, sculpin Cottus spp., three-spined stickleback Gasterosteus aculeatus and Pacific lamprey Entosphenus tridentatus. (Mullan et al 1992, CCCD 2004, Wydoski and Whitney 2003).

\section{Methods- snorkel surveys}

Fish were surveyed by direct observation using single-pass snorkeling as described by Thurow (1994) at 11 sample sites during the summer of 2006 and 15 sampling sites during fall 2006 and winter 2007. 


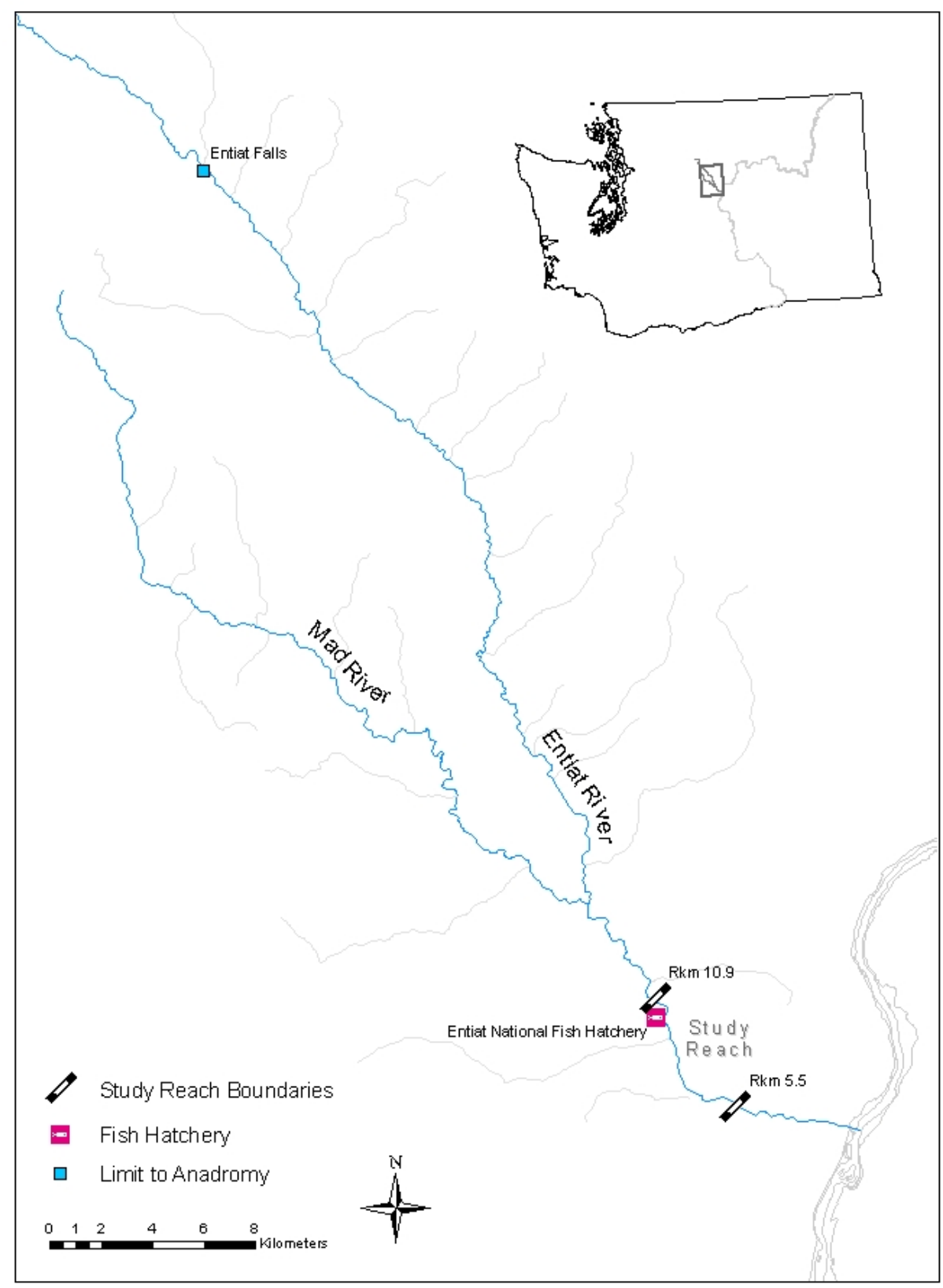

Figure 2. Study reach map of the Entiat River watershed with snorkel survey area from Rkm 0.5 to 34.4 . 


\section{Snorkel site selection}

Snorkel sites locations were identified jointly by USFWS and Terraqua, Inc. Site locations were defined by using locations of proposed habitat structures (treatment sites), locations of existing habitat structures (existing control sites), and information from Rosgen stream typing classification methods to select sites with a similar channel types as treatment sites for sites not subject to modifications (control sites).

Treatment and existing control sites were setup to place the area surveyed in the middle of the section to be modified or presently modified. All control sites and existing control sites were selected upstream of the treatment section. Snorkel sites were defined to be $200 \mathrm{~m}$ in length in the main river sites and $240 \mathrm{~m}$ or less in off-channel sites. Each site was further divided into habitat units, monumented, and flagged.

\section{Snorkel surveys}

Snorkel surveys were conducted at three time periods throughout the year: the summer period (July/August after peak discharge), the fall period (mid-October/November), and the winter period (February/March). During each survey period, snorkeling was conducted at night; however during the summer survey period an additional daytime snorkel was conducted at each site.

Night snorkeling commenced no earlier than 30 minutes past the official sunset at Entiat, WA, or after the first star or planet was observed in the sky. Prior to night snorkeling, glow sticks were affixed at habitat unit breaks to assist crews in defining the sample site.

Up to nine snorkelers and at least one shore tender were used to conduct the snorkel surveys in the mainstem river snorkel sites. Off channel sites were snorkeled by one to four snorkelers depending on the site width. Snorkel crews entered the snorkel site downstream of the site and snorkeled as unit in an upstream direction to the end of that site. Snorkelers were positioned across the stream channel so as to cover the entire channel bank to bank. Shore tenders estimated fish numbers in the water too shallow to snorkel. Snorkelers used dry suits, wet or dry gloves, felt bottom wading boots, a mask and a snorkel. Hand-held dive lights were used at night to illuminate the survey area. Data was recorded by each snorkeler on a PVC cuff secured to their arm and data were transferred to a datasheet at the end of each habitat units. Fish count data from snorkelers was recorded on datasheets by fish size and snorkel lanes looking upstream left to right. Water temperature was collected at the start and end of each site. Turbidity water samples were collected once during the snorkel survey and processed following the snorkel survey. The distance a snorkeler could see underwater water was measure once per day during the fall surveys. All fish observed were counted by species and assigned to a 20mm size class within each habitat unit.

In the office, data were transferred to a database and proofed for concurrence with field datasheets.

Snorkel sites

\section{Results-snorkel surveys}

A total of 15 previous sample sites and nine new sample sites were snorkeled during the August and October 2007 periods. Sites included 12 planned and two completed 
treatment site. Five pre-existing treatment sites were sampled which included four mainriver and one adjacent off-channel site. Five control sites were sampled which included three main river and two off-channel sites (Table 1).

Table 1. Experimental site descriptions and locations snorkeled in the Entiat River during the sample period from August to October 2007.

\begin{tabular}{lcccccc}
\hline \multicolumn{1}{c}{ Site name } & $\begin{array}{c}\text { Experimental } \\
\text { site type }\end{array}$ & $\begin{array}{c}\text { Channel } \\
\text { location }\end{array}$ & $\begin{array}{c}\text { River } \\
\text { kilometer } \\
(\mathbf{k m})\end{array}$ & $\begin{array}{c}\text { Site } \\
\text { length } \\
(\mathbf{m})\end{array}$ & \multicolumn{2}{c}{$\begin{array}{c}\text { Mid-point } \\
\text { coordinates }\end{array}$} \\
\hline City limits main & Treatment & Main & 0.5 & 200 & 47.66320 & Long (W) \\
City limits side channel & Treatment & Off & 0.5 & 200 & 47.66320 & 120.23643 \\
Keystone Canyon & Treatment & Main & 3.7 & 200 & 47.66528 & 120.26584 \\
Milne & Treatment & Main & 4.3 & 200 & 47.66546 & 120.27232 \\
Whitehall cross vane & Treatment & Main & 5.5 & 200 & 47.66920 & 120.28440 \\
PUD canal & Treatment & Off & 5.5 & 240 & 47.66860 & 120.28298 \\
Harrison lower side & Treatment & Off & 6.0 & 200 & 47.67064 & 120.28817 \\
Harrison upper side & Treatment & Off & 6.4 & 200 & 47.66993 & 120.29232 \\
Harrison main & Treatment & Main & 6.4 & 200 & 47.66993 & 120.29232 \\
Dinkelman cross vane & Existing treatment & Main & 7.4 & 200 & 47.67207 & 120.30595 \\
Stanton-Love & Treatment & Main & 8.4 & 200 & 47.67761 & 120.31252 \\
Hanan-Detwiler ditch & Control & Off & 8.4 & 200 & 47.67616 & 120.31201 \\
Jon Small barbs & Existing treatment & Main & 8.8 & 200 & 47.68088 & 120.31263 \\
Knapp-Wham main & Control & Main & 9.3 & 200 & 47.68556 & 120.31562 \\
Knapp-Wham ditch & Control & Off & 9.3 & 100 & 47.68609 & 120.31564 \\
Moen & Treatment & Off & 10.0 & 200 & 47.69201 & 120.31679 \\
Wilson main & Existing treatment & Main & 10.6 & 200 & 47.69548 & 120.32093 \\
Wilson side channel & Existing treatment & Off & 10.6 & 200 & 47.69606 & 120.32128 \\
Hatchery & Control & Main & 10.9 & 200 & 47.69869 & 120.32396 \\
CDLT/ Moraine & Control & Main & 26.5 & 200 & 47.80231 & 120.40202 \\
Deskin / Wortz & Existing treatment & Main & 28.0 & 200 & 47.81224 & 120.41138 \\
Stormy Preserve lower & Treatment & Main & 29.4 & 200 & 47.22001 & 120.42350 \\
Stormy Preserve mid & Treatment & Main & 29.8 & 200 & 47.82387 & 120.42124 \\
Sego/Yurt & Treatment & Main & 34.4 & 200 & 47.86131 & 120.42066 \\
\hline & & & & & &
\end{tabular}

\section{Discharge}

Daily mean discharge for all sites and periods ranged from a low of $131 \mathrm{ft}^{3} / \mathrm{sec}$ during the fall snorkel to a high of $237 \mathrm{ft}^{3} / \mathrm{sec}$ during summer snorkel (Table 2). Daily mean discharge within a sample period varied from $58 \mathrm{ft}^{3} / \mathrm{sec}$ during the summer period to $29 \mathrm{ft}^{3} / \mathrm{sec}$ during the winter period. Snorkel surveys were conducted during low water periods of the year, which is reflected in the seasonal hydrograph (

Figure 3). The summer snorkel surveys were conducted during a period of descending discharge. The fall snorkel survey was conducted during a period of slightly increasing discharge.

\section{Water temperature}

Water temperatures within a sample period varied from $7.1^{\circ} \mathrm{C}$ to $6.3^{\circ} \mathrm{C}$ during the summer and fall sample periods, respectively (Table 2). Mean water temperature for the 
summer period was $16.2^{\circ} \mathrm{C}$ (SD 1.7) and mean water temperature for the fall period was $7.4{ }^{\circ} \mathrm{C}(\mathrm{SD} 1.3)$.

Table 2. Water quality measurements for sites and times snorkeled in the Entiat River during 2007. Mean discharge data is from USGS gage site number 12452990.

\begin{tabular}{|c|c|c|c|c|c|c|}
\hline $\begin{array}{l}\text { Survey period- } \\
\text { snorkel time }\end{array}$ & Site name & $\begin{array}{c}\begin{array}{c}\text { River } \\
\text { kilometer } \\
(\mathbf{k m})\end{array} \\
\end{array}$ & $\begin{array}{c}\text { Snorkel } \\
\text { date } \\
\end{array}$ & $\begin{array}{c}\text { Discharge } \\
\left(\mathrm{ft}^{3} / \mathrm{sec}\right) \\
\end{array}$ & $\begin{array}{c}\text { Temperature } \\
{ }^{\circ} \mathrm{C} \\
\end{array}$ & $\begin{array}{c}\text { Turbidity } \\
\text { NTU } \\
\end{array}$ \\
\hline \multirow[t]{24}{*}{ Summer-day } & City limits main & 0.5 & $8 / 10 / 2007$ & 219 & 16.8 & 0.85 \\
\hline & City limits side channel & 0.5 & $8 / 10 / 2007$ & 219 & 17.5 & 0.85 \\
\hline & Keystone Canyon & 3.7 & 8/8/2007 & 233 & 17.9 & 0.88 \\
\hline & Milne & 4.3 & 8/8/2007 & 233 & 16.2 & 0.88 \\
\hline & PUD canal & 5.5 & $8 / 13 / 2007$ & 199 & 14.4 & 0.68 \\
\hline & Whitehall cross vane & 5.5 & $8 / 13 / 2007$ & 199 & 15.9 & 0.68 \\
\hline & Harrison lower side & 6.0 & $8 / 15 / 2007$ & 180 & 20.2 & 0.97 \\
\hline & Harrison main & 6.4 & $8 / 13 / 2007$ & 199 & 14.4 & 0.75 \\
\hline & Harrison upper side & 6.4 & $8 / 15 / 2007$ & 180 & 14.7 & NA \\
\hline & Dinkelman cross vane & 7.4 & $8 / 14 / 2007$ & 188 & 15.4 & 0.82 \\
\hline & Hanan-Detwiler ditch & 8.4 & 8/7/2007 & 237 & 18.9 & 2.03 \\
\hline & Stanton-Love & 8.4 & 8/9/2007 & 227 & 14.7 & 0.85 \\
\hline & Jon Small barbs & 8.8 & 8/10/2007 & 219 & 14.5 & 0.61 \\
\hline & Knapp-Wham ditch & 9.3 & $8 / 14 / 2007$ & 188 & 18.0 & 0.86 \\
\hline & Knapp-Wham main & 9.3 & $8 / 14 / 2007$ & 188 & 18.0 & 0.86 \\
\hline & Moen & 10.0 & $8 / 15 / 2007$ & 180 & 15.3 & 0.72 \\
\hline & Wilson side channel & 10.6 & 8/7/2007 & 237 & 16.4 & 2.12 \\
\hline & Wilson main & 10.6 & 8/9/2007 & 227 & 17.0 & 0.90 \\
\hline & Hatchery & 10.9 & $8 / 14 / 2007$ & 188 & 17.1 & 0.84 \\
\hline & CDLT/ Moraine & 26.5 & $8 / 16 / 2007$ & 179 & 17.5 & 0.97 \\
\hline & Deskin / Wortz & 28.0 & $8 / 16 / 2007$ & 179 & 16.8 & 1.30 \\
\hline & Stormy Preserve lower & 29.4 & 8/16/2007 & 179 & 14.2 & 0.62 \\
\hline & Stormy Preserve mid & 29.8 & $8 / 16 / 2007$ & 179 & 14.4 & 0.62 \\
\hline & Sego/Yurt & 34.4 & $8 / 16 / 2007$ & 179 & 13.1 & 0.41 \\
\hline \multirow[t]{16}{*}{ Fall-night } & City limits main & 0.5 & $10 / 19 / 2007$ & 143 & 7.5 & 1.56 \\
\hline & City limits side channel & 0.5 & $10 / 19 / 2007$ & 143 & 7.0 & 1.56 \\
\hline & Keystone Canyon & 3.7 & $10 / 16 / 2007$ & 131 & 9.0 & 1.62 \\
\hline & Milne & 4.3 & $10 / 15 / 2007$ & 131 & 9.5 & 1.56 \\
\hline & PUD canal & 5.5 & $10 / 18 / 2007$ & 136 & 6.5 & 1.25 \\
\hline & Whitehall cross vane & 5.5 & $10 / 18 / 2007$ & 136 & 6.0 & 0.81 \\
\hline & Harrison lower side & 6.0 & $10 / 23 / 2007$ & 160 & 11.3 & 1.39 \\
\hline & Harrison main & 6.4 & $10 / 19 / 2007$ & 143 & 6.8 & 0.88 \\
\hline & Harrison upper side & 6.4 & $10 / 23 / 2007$ & 160 & NA & NA \\
\hline & Dinkelman cross vane & 7.4 & $10 / 18 / 2007$ & 136 & 5.0 & 1.31 \\
\hline & Hanan-Detwiler ditch & 8.4 & $10 / 17 / 2007$ & 132 & 7.3 & 1.14 \\
\hline & Stanton-Love & 8.4 & $10 / 17 / 2007$ & 132 & 7.3 & 1.14 \\
\hline & Jon Small barbs & 8.8 & $10 / 15 / 2007$ & 131 & 8.5 & 1.02 \\
\hline & Knapp-Wham ditch & 9.3 & $10 / 17 / 2007$ & 132 & 7.0 & 1.12 \\
\hline & Knapp-Wham main & 9.3 & $10 / 17 / 2007$ & 132 & 7.5 & 1.14 \\
\hline & Moen & 10.0 & $10 / 23 / 2007$ & 160 & 8.0 & 0.77 \\
\hline
\end{tabular}


Table 2. Water quality measurements for sites and times snorkeled in the Entiat River from 2006 to 2007. Mean discharge data is from USGS gage site number 12452990, continued.

\begin{tabular}{|c|c|c|c|c|c|c|}
\hline $\begin{array}{l}\text { Survey period- } \\
\text { snorkel time }\end{array}$ & Site name & $\begin{array}{c}\begin{array}{c}\text { River } \\
\text { kilometer } \\
(\mathbf{k m})\end{array} \\
\end{array}$ & $\begin{array}{c}\text { Snorkel } \\
\text { date }\end{array}$ & $\begin{array}{c}\text { Discharge } \\
\left(\mathrm{ft}^{3} / \mathrm{sec}\right)\end{array}$ & $\begin{array}{c}\text { Temperature } \\
{ }^{\circ} \mathrm{C} \\
\end{array}$ & $\begin{array}{c}\text { Turbidity } \\
\text { NTU } \\
\end{array}$ \\
\hline & Wilson main & 10.6 & $10 / 17 / 2007$ & 132 & 7.0 & 1.34 \\
\hline & Wilson side channel & 10.6 & $10 / 17 / 2007$ & 132 & 6.8 & 6.51 \\
\hline & Hatchery & 10.9 & $10 / 16 / 2007$ & 131 & 8.5 & NA \\
\hline & CDLT/ Moraine & 26.5 & $10 / 22 / 2007$ & 140 & 7.0 & 0.70 \\
\hline & $\begin{array}{l}\text { Deskin / Wortz } \\
\text { Stormy Preserve }\end{array}$ & 28.0 & $10 / 23 / 2007$ & 160 & 7.0 & 0.53 \\
\hline & lower & 29.4 & $10 / 22 / 2007$ & 140 & 6.8 & 0.41 \\
\hline & Stormy Preserve mid & 29.8 & $10 / 22 / 2007$ & 140 & 6.8 & 0.41 \\
\hline & Sego/Yurt & 34.4 & $10 / 23 / 2007$ & 160 & 6.5 & 0.55 \\
\hline
\end{tabular}

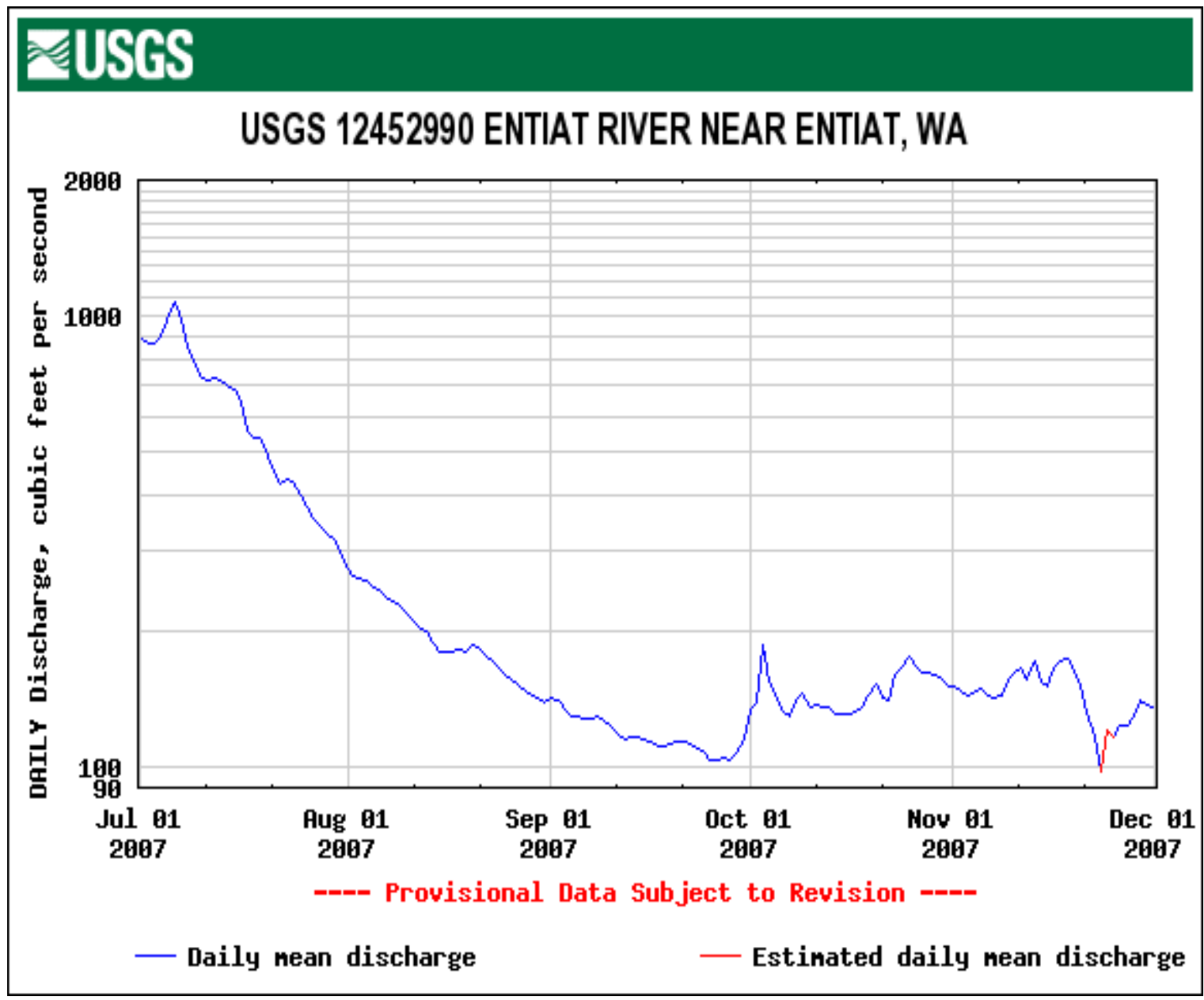

Figure 3. Daily mean discharge $\left(\mathrm{ft}^{3} / \mathrm{sec}\right)$ for the period from July 1, 2007 to December 1 , 2007 for USGS gage station 12452990 at Rkm 2.3 in the Entiat River. 


\section{Turbidity}

Mean water turbidity by period was 0.9 NTU during the summer period and $1.3 \mathrm{NTU}$ during the fall period (Table 2).

Overall snorkel survey count

All snorkel sites were successfully snorkeled during planned periods and times of day. A total of 37,938 fish were counted from all time periods and sites during August and October 2007 (Table 3). The greatest number of fish observed was during the summer period with $75 \%$ of the overall total for the two periods.

Table 3. The number of fish species observed by period and time of day during snorkel surveys in the Entiat River during August and October 2007.

\begin{tabular}{lccc}
\hline \multicolumn{1}{c}{ Fish } & $\begin{array}{c}\text { Summer } \\
\text { species }\end{array}$ & $\begin{array}{c}\text { Fall } \\
\text { Naght }\end{array}$ & Total \\
\hline Brook trout & 0 & 2 & 2 \\
Bull trout & 5 & 14 & 19 \\
Chinook salmon & 3,000 & 2,770 & 5,770 \\
Chiselmouth & 3 & 0 & 3 \\
Coho salmon & 14 & 2 & 16 \\
Cutthroat trout & 1 & 4 & 5 \\
Dace spp. & 1,045 & 987 & 2,032 \\
Lamprey spp. & 2 & 6 & 8 \\
Mountain whitefish & 2,081 & 423 & 2,504 \\
Northern pikeminnow & 10 & 0 & 10 \\
Redside shiner & 35 & 498 & 533 \\
Sculpin spp. & 62 & 184 & 246 \\
Steelhead/rainbow trout & 1,737 & 1,916 & 3,653 \\
Sucker spp. & 588 & 891 & 1,479 \\
Three-spine stickleback & 14 & 1,786 & 1,800 \\
Unknown fish & 19,321 & 537 & 19,858 \\
Grand total & & & 37,938 \\
\hline
\end{tabular}

For fish identified to species or genera, Chinook salmon comprised $15 \%$ of the total fish observed followed by rainbow trout (10\%), mountain whitefish (7\%), dace spp. (5\%), three-spine stickleback (5\%), and sucker spp. (4\%). Unidentified species/genera fish comprised 52\% of the observed fish and were primarily juvenile or larval fish observed in water too shallow to snorkel along the river margins during the summer period. The remaining percentage of fish identified to species/genera ( $2 \%$ ) were comprised of bull trout, chiselmouth, coho salmon, cutthroat trout, lamprey spp., northern pikeminnow, redside shiner, and sculpin spp. 


\section{Discussion-snorkel surveys}

Snorkel surveys conducted by the MCRFRO in the Entiat River from August 2007 to October 2007 as part of the Integrated Status and Effectiveness Monitoring Program in the Entiat River were conducted on time and within the planned sample periods. These snorkel surveys were conducted under decreasing or low flows and low turbidity conditions creating ideal snorkeling conditions.

Starting with the summer 2007 survey period, nine new treatment sites were added to the snorkeling schedule.

During this period of the project two snorkel sites were modified using restoration methods. The Milne was treated using rock barbs and a rock structure at the water intake back water area. At the downstream end of the Stanton-Love control site, a cross vein structure was installed. This main river structure also diverts water to the Hanan-Detwiler canal. No modifications were made to the Hanan-Detwiler canal downsteam of the headgate. All construction occurred between the summer and fall 2007snorkel surveys. The creation of a large pool at the Stanton-Love site and subsequent disturbed gravel substrate provided habitat for spawning summer Chinook salmon which congregated in large number at that site during the fall 2007 survey. Additionally, at the Milne site in areas of disturbed substrate summer Chinook were observed spawning

Project goals were met during the 2007 field season. Continued snorkel surveys will be needed to evaluate the before and after restoration efforts and meet the long-term effectiveness monitoring program goals in the Entiat River.

\section{Methods-rotary screw trap}

Rotary screw trap operation

Two $5 \mathrm{ft}$ diameter rotary screw traps manufactured by EG Solutions Inc. were used during this study to capture downstream migrating salmonids. The traps were retrofitted with pontoons from $8 \mathrm{ft}$ style screw traps to facilitate better floatation and safety in higher flow regimes. Additionally a debris door was placed on each trap cone and each trap was outfitted with a spray bar to pressure wash away accumulated algae that clogs the cone screen. Trap operations followed operational permit guidelines as per Chelan County Shoreline Management Act (file\# SE 06-016 US Fish and Wildlife Service Fish Enhancement letter dated August 16, 2006), WDFW Temporary Use Permit (dated 11/27/07), and two Hydraulic Project Approvals (log\#ST-F8213-01, upper trap dated 3/13/03 and control\#106898-1, lower trap, dated 11/21/06). Assembled traps were lowered into the river via a boom truck and attached to $1 / 4$ inch aircraft cable that was anchored upstream to the base large cottonwood trees. A bridge at the upper trap site and a cross cable at the lower trap site suspended the anchor cable above the stream from the anchor point to the trap. A system of winches and pulleys were utilized throughout the season to guide the trap within the river as flow regimes changed. Traps were positioned weekly in an effort to target an ideal rotational speed per minute (RPM) of 10. Once a position was chosen the trap remained, if possible, in this position for a week or longer to coincide with any ongoing trap efficiency tests (discussed below). The traps operated 
seven days a week from March through November with allowances for extreme weather events. If possible traps were primarily operated 24 hours a day, however, during high flows and increased debris load the traps were operated from twilight to sunrise. At times during extreme discharge events the traps were pulled and taken out of operation until such time that river conditions warranted reinitiating operations.

\section{Fish handling}

Fish handling procedures were conducted in accordance with WDFW Scientific Collection Permits \#07-147-151 (dated 4/11/07), NOAA Permit 119 modification 2 (F/NWR3 dated 6/15/05 and F/NWR/2006/04329 dated 9/18/06) and USFWS Subpermit No. MCRFO-10 (dated 3/31/06).

At least once a day, juvenile fish were transported from the live box of each trap into 5 gallon buckets for tagging and biological sampling. The buckets were equipped with aerators and a light salt $(\mathrm{NaCl})$ solution (1 tbs/gal.) was added to minimize stress during transport and holding. The fish were transported to the ENFH, where a permanent, on-site electronic fish handling/tagging station has been built.

All fish species collected for biological sampling were anesthetized in a water bath with a measured amount of tricaine (MS-222) buffered with sodium bicarbonate to stage 3 or 4 as described in the Stages of Anesthesia by Summerfelt and Smith (1990). Small groups of fish were anesthetized at any one time during daily handling to reduce the chance of incidental mortality from anesthetic overdose. All fish were identified to species with the exception of sculpin, dace, sucker, and whitefish.Chinook sub-yearling juveniles were further broken down into run categories (spring or summer) following a nadir in latesummer run timing abundance. Previous trapping indicates that this occurs annually in mid-August to early-September. Summer Chinook juveniles exit the system from midsummer peaks and spring Chinook sub-yearlings begin to increase with mid-autumn peaks in abundance. Past the late-summer nadir and continuing into autumn, spring and summer Chinook sub-yearlings were split based on nadirs in fork length. This is an assumption based on the belief that spring Chinook juveniles have a size/growth advantage relative to their summer counterparts that is carried over from differences in adult spawn timing.

In addition to species identification and Chinook run classification, both steelhead and Chinook were further ascribed to a life history stage as either fry $(<60 \mathrm{~mm})$, parr $(>60 \mathrm{~mm}$ and distinctive parr marks), transitional ( $>60 \mathrm{~mm}$ silver sheen, faint parr marks) or smolt (>60mm silver sheen with absent parr marks with possible black tipped caudal). Stage classification may provide a useful metric to gauge migratory readiness in juveniles and may help serve to separate resident "rainbow" from the migratory steelhead juveniles.

A minimum of 30 fish per species and life stage were measured to the nearest millimeter of fork length and all salmonids greater than $60 \mathrm{~mm}$ were weighed to the nearest tenth of a gram. After handling all juveniles are allowed to fully recover prior to release. Nontagged juveniles are released approximately 400 meters downstream from the trap after a minimum one hour of recovery time. 
PIT tagging of juvenile Chinook, steelhead, and bull trout follows the procedures and file submission requirements outlined by Pacific State Marine Fisheries Commission PIT Tag Information System (PTAGIS) in addition to juvenile PIT tagging procedures described in by the ISEMP Upper Columbia River Basin Protocol (Nelle 2007). Chinook, steelhead, and bull trout greater than $60 \mathrm{~mm}$ of forklength were tagged using a disinfected hollow needle to insert a PIT tag $(134.2 \mathrm{kHz}$ tags $11.5 \mathrm{~mm} / 0.06 \mathrm{gm})$ into the abdominal cavity. All PIT tagged juveniles are measured to the nearest millimeter $(\mathrm{mm})$ in fork length and weighed to the nearest tenth of a gram (gm) and any injuries are noted. Juveniles are not PIT tagged if determined to have a recent or substantial injury that may become aggravated through tagging. PIT tagged fish were generally held 24 hrs at ENFH to monitor survival and tag retention. A maximum of 72 hours hold time was instituted on all tagged fish.

\section{Data entry}

All individual fish data entry utilized the P3 program from PTAGIS. P3 is a data entry application program required to collect and submit information about marked or recaptured fish with a PIT tag in the Columbia River Basin. USFWS utilized this program as a tool to enter all fish information regardless of whether the fish was marked with a PIT tag. P3 serves as a Microsoft Access ${ }^{\mathrm{TM}}$ overlay which allows communication with peripheral devices. USFWS peripheral devices included a Destron Fearing FS2001ISO transceiver/antenna for reading PIT tags, a GTCO Calcomp DrawingBoard III digitizing board and a GSE 350 electronic balance for automating data entry into a laptop computer. Utilizing a custom Access ${ }^{\mathrm{TM}}$ database designed by Environmental Data Services (contact: Steve Rentmeester), P3 generated files could then be automatically parsed into the ISEMP database. The original P3 file was left intact and subsequently uploaded to PTAGIS. From this database, PIT tag information is parsed and housed for use by researchers throughout the Columbia River Basin.

\section{Remote capture for PIT tagging}

A large segment of PIT tagged fish are collected via rotary screw traps. However, the number of juvenile fish of minimum length $(>60 \mathrm{~mm})$ to be PIT tagged at the trap is generally short of the recommended 5,000 tagged steelhead/rainbow trout and 5,000 spring Chinook salmon needed from each sub-basin to effectively estimate life-stage survival rates (Hillman 2006). In addition, the rotary screw traps capture only currently migrating juveniles and data obtained via tag monitoring represent movement and survival outside of the Entiat Basin as these juveniles migrate through the Columbia River hydro-corridor to the ocean. To increase the number of tagged fish and to improve information regarding within basin survival and migration timing, non-migratory juvenile spring Chinook and steelhead rearing within the watershed were targeted for capture and subsequent tagging. As part of a collaborative effort with the Washington Department of Fish and Wildlife (WDFW) "remote tagging” was conducted throughout the Entiat River and its main tributary, the Mad River during the months of July -September.

Remote tagged steelhead and spring Chinook salmon were primarily caught using: angling, and snorkel herding. Angling capture consisted of single barbless flies (size 14 and smaller) on light fly fishing gear. Snorkel herding utilized a team of in-stream snorkelers and a beach seine net to target and capture juvenile salmonids. Remote capture and PIT tagging activities were limited to temperature regimes below $17^{\circ} \mathrm{C}$. Collected 
juveniles were tagged and released near their capture location generally on the same day of capture.

\section{Genetic and scale sampling}

Throughout the migration, all captured bull trout, and subset of spring Chinook salmon and steelhead juveniles were sampled for genetic and age analysis, as per the Upper Columbia River Monitoring Strategy (Hillman 2006). This type of sampling is nonlethal. Genetic sampling involved taking a small clip of tissue from either the ventral (steelhead \& spring Chinook) or caudal fin (bull trout) and scales were collected from steelhead only utilizing a scalpel to gently scrape scales onto the blade prior to placement on a gum card. Steelhead tissue and scales were sent to the WDFW Office in Wenatchee and Chinook and bull trout tissue were sent to the Region 1 USFWS genetics lab for future analysis.

Screw trap efficiency

A portion of the collected Chinook and steelhead were used to estimate trap capture efficiency. Captured fish were pooled for 72 hours and released upstream of the capture origin. All fish used for efficiency trials were PIT tagged ( $>60 \mathrm{~mm}$ FL) or dye marked $(<60 \mathrm{~mm}$ FL) with Bismark brown. Marked fish were placed in a live box located at ENFH for holding ( $<72$ hrs) prior to release. Marked fish were transported to release sites using 5 gallon buckets with aerators to minimize stress. Juvenile fish used for efficiency trials were released at twilight upstream of each trap. The release location for the upper trap was located primarily (dyed fry released at ENFH intake, rkm 8) at rkm 18 (Mad River road bridge) for the upper trap and rkm 2.3 (Keystone Ranch private bridge) for the lower trap site. PIT tagged recaptured fish were subsequently re-measured and released to document growth rates since time of first capture. Fish recaptured at the same trap twice were removed from the daily catch estimate.

\section{Water temperature and discharge}

Water temperature was monitored by a Davis Vantage Pro2 wireless weather station and water quality monitor. Water temperatures were verified with analog instruments to verify accuracy. Discharge was monitored by a USGS station number 12452990, located at $\mathrm{Rkm} 2.3$.

\section{Results-rotary screw trap}

\section{Trap operation time}

From August $1^{\text {st }}$ through November $19^{\text {th }}$ there was 111 days available to trap, of these a total of 5 days (4.5\%) were lost to rotary screw trap capture (Table 4). An over abundance of debris and falling leaves from wind events, was the main contributor for the lost trapping days in late October through November. 
Table 4. Rotary screw trap operation time from August through November 2007.

\begin{tabular}{lccc}
\hline Month & Days available & Days In operation & Days Pulled \\
\hline August & 31 & 31 & 0 \\
September & 30 & 30 & 0 \\
October & 31 & 30 & 1 \\
November & 19 & 15 & 4 \\
\hline
\end{tabular}

Juvenile emigration

During this study period, the month of August proved the most productive capture month for juvenile steelhead and Chinook. Wild summer Chinook dominated the out migration during August with 3,418 of the total 3,420 Chinook captured. Average length and weight of juvenile summer Chinook in August was $68.4 \mathrm{~mm}$ (SD 15.6) and $4.9 \mathrm{~g}$ (SD 4.2) (Table 5 and Figure 4) and wild spring Chinook yearlings were 178.0 and 60.4. A total of 301juvenile steelhead implanted with PIT tags had an average length of $164.4 \mathrm{~g}$ (SD 27.1) and weight of $50.4 \mathrm{~g}$ (SD 21.8) (Table 5). Sub-yearling O. mykiss (<60 mm) began to show up in catch totals starting in late August and September, and peaked in October (Figures 5, 7 and 9). In September Chinook migration was dominated by spring run (82.9\%) with an average length of $83.1 \mathrm{~mm}$ (SD 12.4). Whereas summer run Chinook averaged $69.8 \mathrm{~mm}$ (SD 11.7) through the month. The length frequency distribution of Chinook in September was separated by two distinct groups: 50-75 mm (summer Chinook), and 80-105 mm (spring Chinook) (Figure 6). A similar trend in length frequency for Chinook was observed in October, with a bimodal distribution peaking at 75 and 95 mm, respectively (Figure 8). November Chinook catch remained productive (1,046 spring Chinook) even with the limited run time (15 days) (Table 4). Steelhead catch dropped through the month (44), but length and weight averages peaked in November. At least two separate age classes were apparent for O. mykiss in November, based on length frequency distribution (Figure 11). 
Table 5. Juvenile salmonid catch and PIT tag totals from Entiat River rotary screw traps.

\begin{tabular}{|c|c|c|c|c|c|c|}
\hline & Species & Caught & Sampled & PIT Tagged & Mean Length (mm) & Mean Weight (g) \\
\hline \multirow[t]{5}{*}{ August } & Wild Spring Chinook & 2 & 2 & 2 & 178.0 & 60.4 \\
\hline & Wild Summer Chinook & 3418 & 1897 & 1561 & 68.4 & 4.9 \\
\hline & Wild Steelhead/Rainbow & 337 & 331 & 301 & 165.0 & 50.4 \\
\hline & Wild Coho & 0 & 0 & 0 & 0.0 & 0.0 \\
\hline & Bull Trout & 1 & 1 & 1 & 185.0 & 58.1 \\
\hline \multirow[t]{5}{*}{ September } & Wild Spring Chinook & 800 & 754 & 696 & 83.1 & 6.0 \\
\hline & Wild Summer Chinook & 164 & 160 & 87 & 69.8 & 5.0 \\
\hline & Wild Steelhead/Rainbow & 178 & 172 & 163 & 168.9 & 54.6 \\
\hline & Wild Coho & 0 & 0 & 0 & 0.0 & 0.0 \\
\hline & Bull Trout & 0 & 0 & 0 & 0.0 & 0.0 \\
\hline \multirow[t]{5}{*}{ October } & Wild Spring Chinook & 2035 & 1951 & 1684 & 85.0 & 6.4 \\
\hline & Wild Summer Chinook & 35 & 35 & 0 & 57.3 & $\mathrm{n} / \mathrm{a}$ \\
\hline & Wild Steelhead/Rainbow & 165 & 161 & 147 & 161.6 & 42.9 \\
\hline & Wild Coho & 7 & 7 & 0 & 148.7 & 49.7 \\
\hline & Bull Trout & 4 & 4 & 4 & 239.5 & 132.5 \\
\hline \multirow[t]{6}{*}{ November } & Wild Spring Chinook & 1049 & 1046 & 928 & 90.7 & 7.3 \\
\hline & Wild Summer Chinook & 3 & 3 & 0 & 59.0 & $\mathrm{n} / \mathrm{a}$ \\
\hline & Wild Steelhead/Rainbow & 44 & 44 & 37 & 174.1 & 42.7 \\
\hline & Wild Coho & 0 & 0 & 0 & 0.0 & 0.0 \\
\hline & Bull Trout & 15 & 15 & 13 & 201.4 & 77.9 \\
\hline & Season Totals & 8,257 & 6,274 & 5,624 & & \\
\hline
\end{tabular}


August 2007 Wild Chinook Length Frequency Distribution

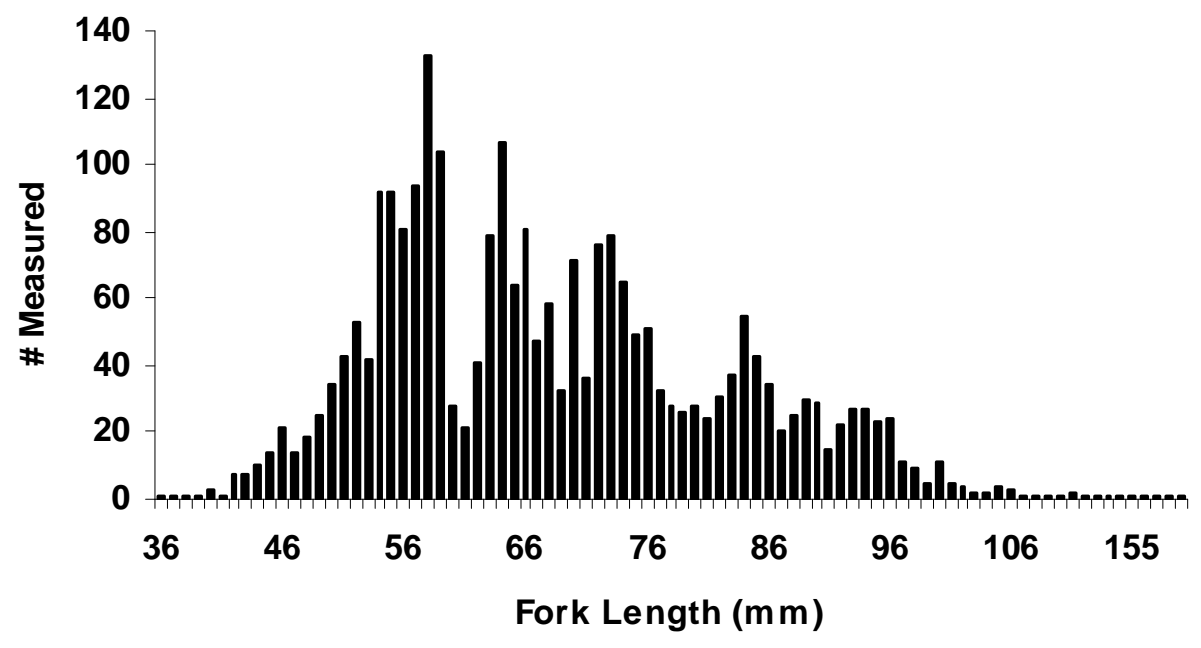

Figure 4. Length frequency distribution of wild Chinook captured from Entiat River rotary screw traps August 2007.

August 2007 Wild Steelhead Length Frequency Histogram

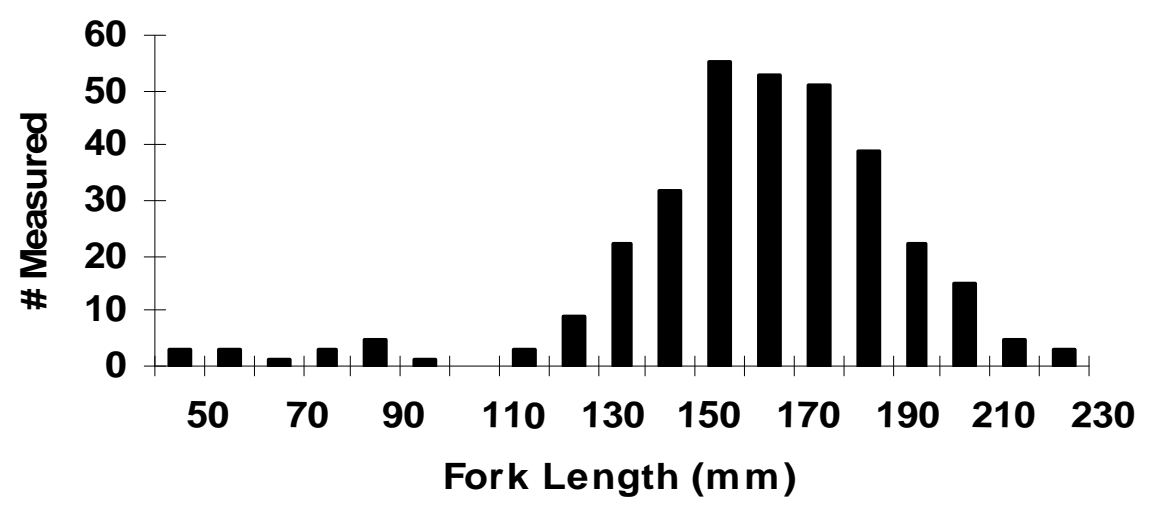

Figure 5. Length frequency distribution of wild steelhead captured from Entiat River rotary screw traps August 2007. 


\section{Septem ber 2007 Wild Chinook Length Frequency Distribution}

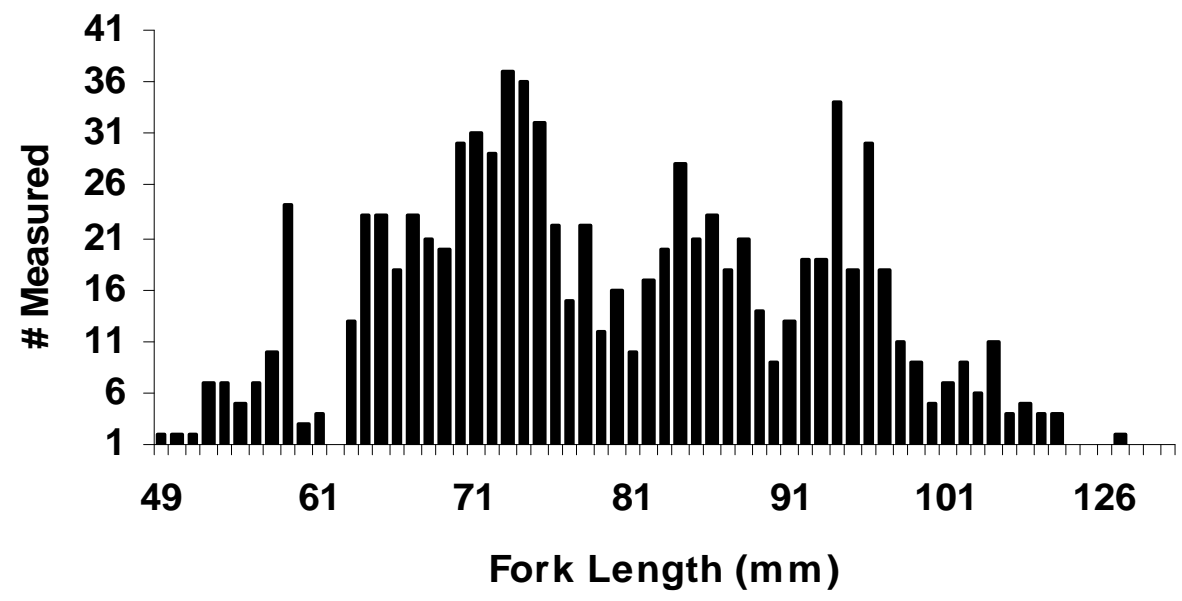

Figure 6. Length frequency distribution of wild Chinook captured from Entiat River rotary screw traps September 2007.

September 2007 Wild Steelhead Length

Frequency Distribution

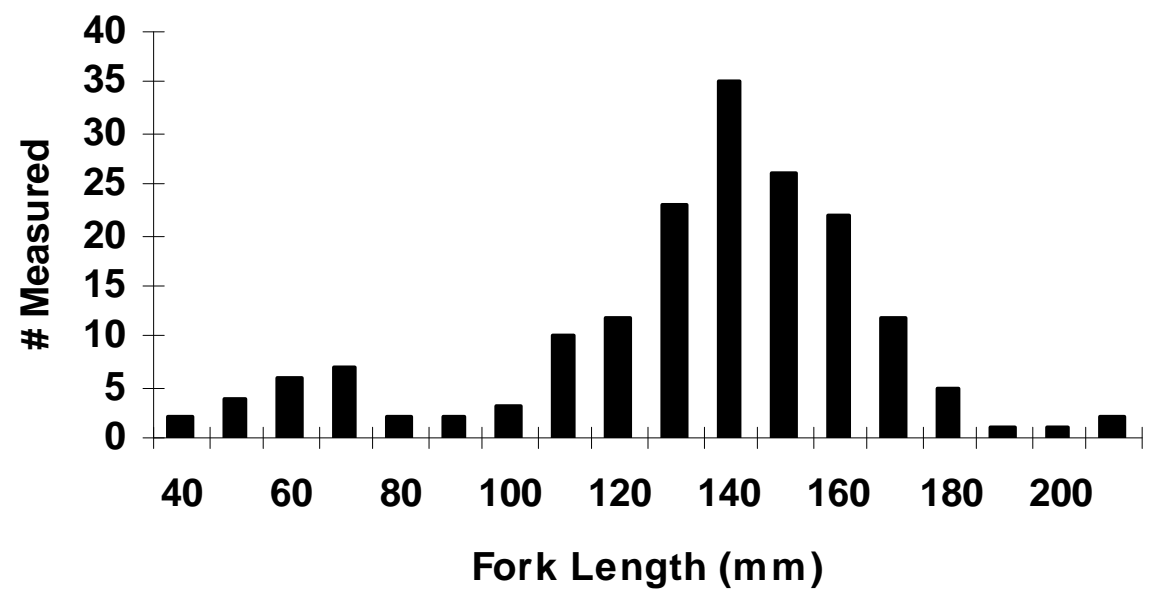

Figure 7. Length frequency distribution of wild steelhead captured from Entiat River rotary screw traps September 2007. 


\section{October 2007 Wild Chinook Length Frequency \\ Distribution}

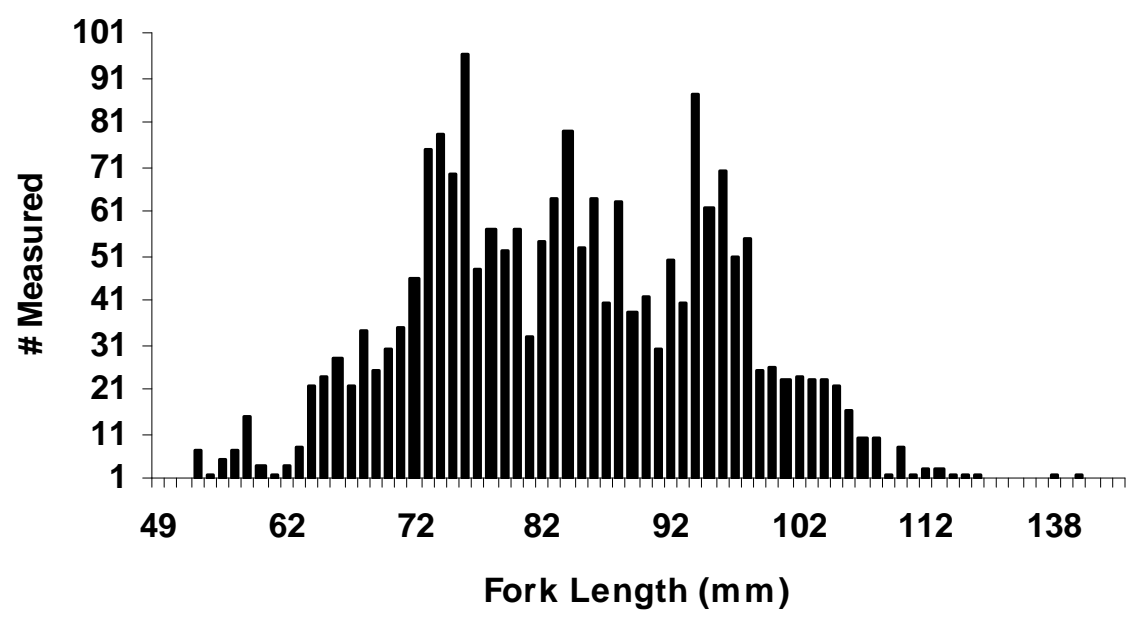

Figure 8. Length frequency distribution of wild Chinook captured from Entiat River rotary screw traps October 2007.

\section{October 2007 Wild Steelhead Length Frequency Histogram}

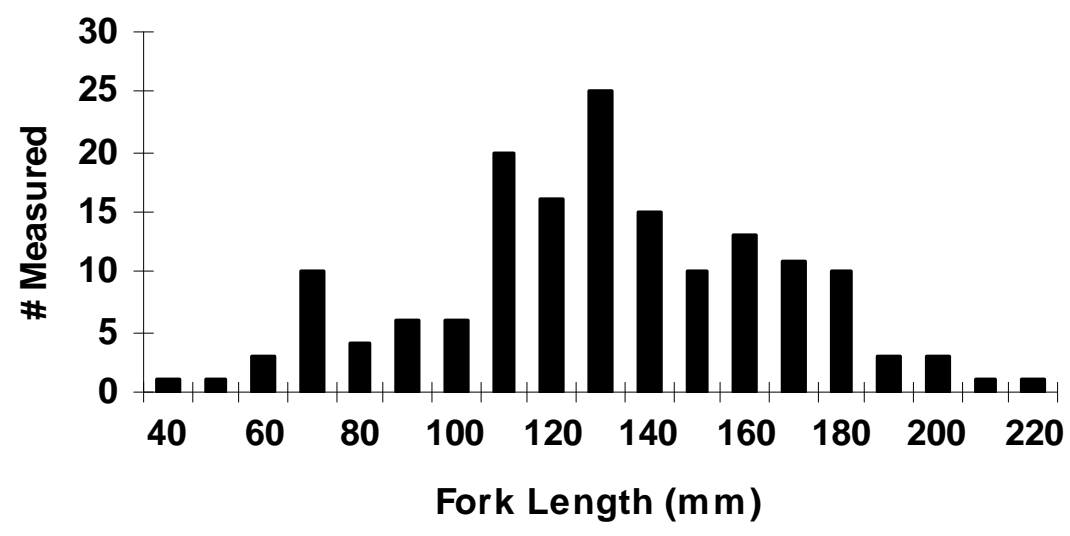

Figure 9. Length frequency distribution of wild steelhead captured from Entiat River rotary screw traps October 2007. 
Novem ber 2007 Wild Chinook Length Frequency

Distribution

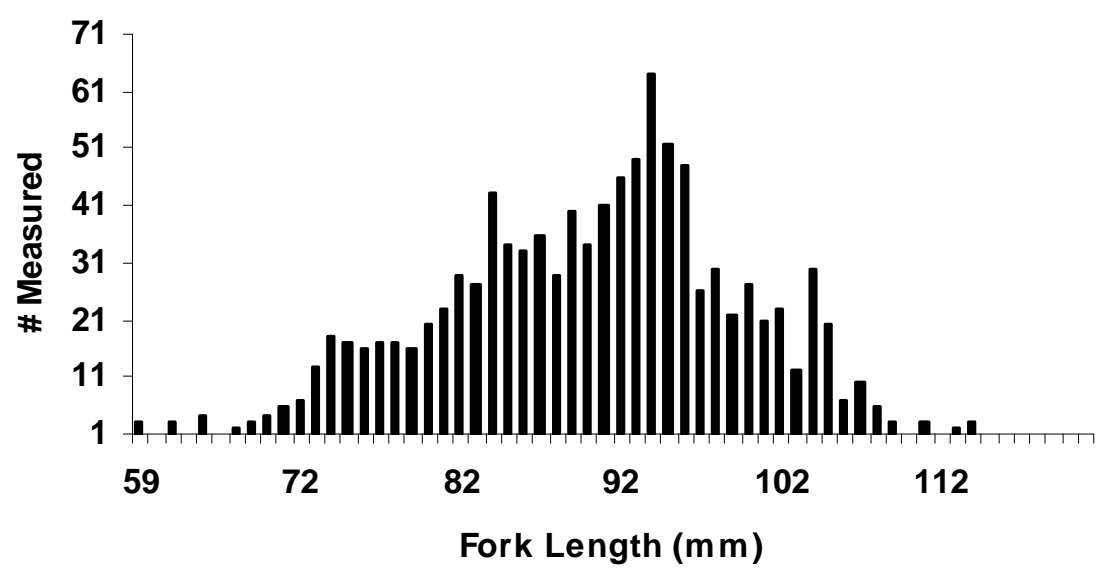

Figure 10. Length frequency distribution of wild Chinook captured from Entiat River rotary screw traps November 2007.

Novem ber 2007 Wild Steelhead Length Frequency Distribution

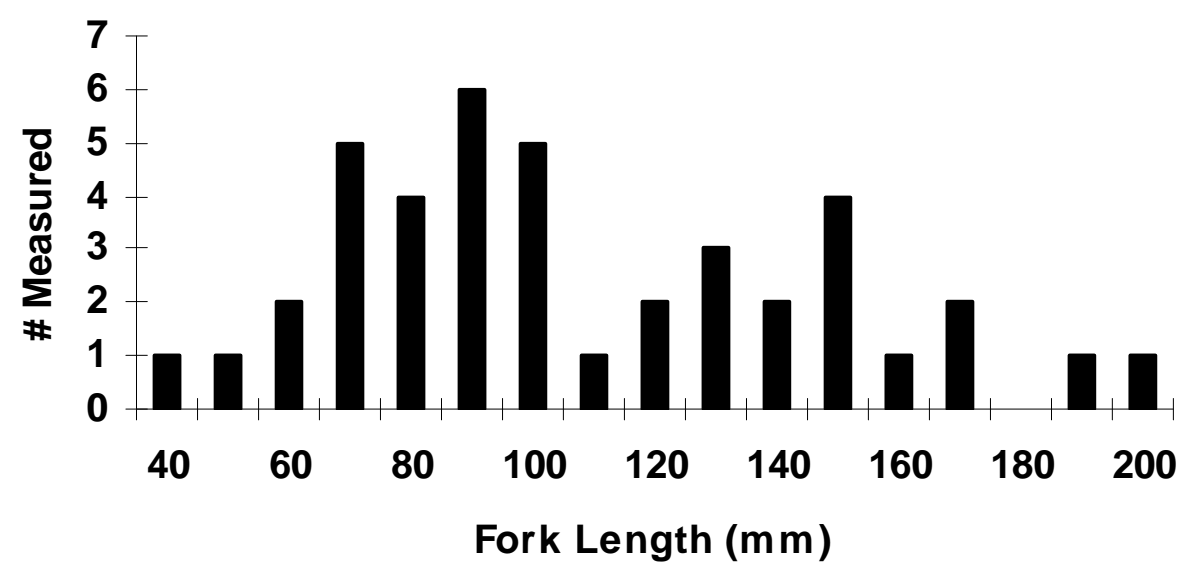

Figure 11. Length frequency distribution of wild steelhead captured from Entiat River rotary screw traps November 2007. 


\section{Remote tagging operations}

A total of 464 juvenile salmonids were tagged at remote locations spread throughout the Entiat River watershed. Of the 464 fish, 315 were wild steelhead/rainbow and 149 were Chinook. For gear capture type, angling dominated by effort, total catch and catch rate (323 fish captured, 72 hours of effort, 4.5 fish/hr, 96\% steelhead). Angling was the most effective method to catch steelhead/rainbow while, snorkel-herding (172 fish captured, 51 hours of effort, 2.5 fish/hr, 97\% Chinook) and minnow traps (16 fish captured, 6 hours of effort, $2.7 \mathrm{hrs} /$ fish, 100\% Chinook) appeared the most effective at capturing Chinook. By stream habitat type angling proved to be the most productive method in boulder dominated riffles and steeper gradients such as those often encountered in the lower reaches of the Mad River, whereas snorkel-herding tactics and minnow traps proved a reliable capture method in low gradient reaches, back channels, and debris jams such as those found at various locations in the main stem Entiat River (Table 6).

Table 6. Remote PIT tag summary data from August through November 2007.

\begin{tabular}{cllccc}
\hline Date & Tributary & Method & $\begin{array}{c}\text { Effort } \\
\text { (hours) }\end{array}$ & $\begin{array}{c}\text { Chinook } \\
\text { Tagged }\end{array}$ & $\begin{array}{c}\text { Steelhead } \\
\text { Tagged }\end{array}$ \\
\hline $8 / 13 / 2007$ & Mad & Angling & 8 & 1 & 34 \\
$8 / 16 / 2007$ & Mad & Angling & 9 & 2 & 48 \\
$8 / 17 / 2007$ & Mad & Angling & 16 & 1 & 46 \\
$8 / 20 / 2007$ & Mad & Angling & 7 & 0 & 6 \\
$9 / 12 / 2007$ & Mad & Angling & 16 & 3 & 82 \\
$9 / 13 / 2007$ & Mad & Angling & 16 & 5 & 95 \\
& & total & $\mathbf{7 2}$ & $\mathbf{1 2}$ & $\mathbf{3 1 1}$ \\
$9 / 11 / 2007$ & Entiat & Minnow & 1.5 & 3 & 0 \\
$9 / 13 / 2007$ & Entiat & Minnow & 1.5 & 6 & 0 \\
$9 / 14 / 2007$ & Entiat & Minnow & 1.5 & 4 & 0 \\
$9 / 16 / 2007$ & Entiat & Minnow & 1.5 & 3 & 0 \\
9/17/2007 & Entiat & Snerd & 30 & 106 & 3 \\
$9 / 18 / 2007$ & Entiat & Snerd & 21 & 15 & 1 \\
& & total & $\mathbf{5 7}$ & $\mathbf{1 3 7}$ & $\mathbf{4}$ \\
\hline
\end{tabular}

\section{Water temperature and discharge}

Entiat River average water temperature ranged from $17^{\circ} \mathrm{C}$ in August to $4.5^{\circ} \mathrm{C}$ in November. Throughout the season, total juvenile catch appeared inversely related to water temperature. This was best illustrated by the month of September where mean daily water temperatures stayed in excess of $13^{\circ} \mathrm{C}$, and catch totals remained low at both traps. As mean water temperature fell to $10^{\circ} \mathrm{C}$ in early October (Figure 12) daily capture rates rose substantially. In terms of river flow, total discharge during the study period peaked in early August at $275 \mathrm{cfs}$, dropped to a low of approximately $100 \mathrm{cfs}$ in late September, and averaged $154.4 \mathrm{cfs}$ (SD 37.8) throughout this study period. Compared to temperature, discharge appears positively related to capture rates. This relation was readily apparent as rain events in late August and the first week of October, were followed with increased trap captures on succeeding days (Figure 13). 


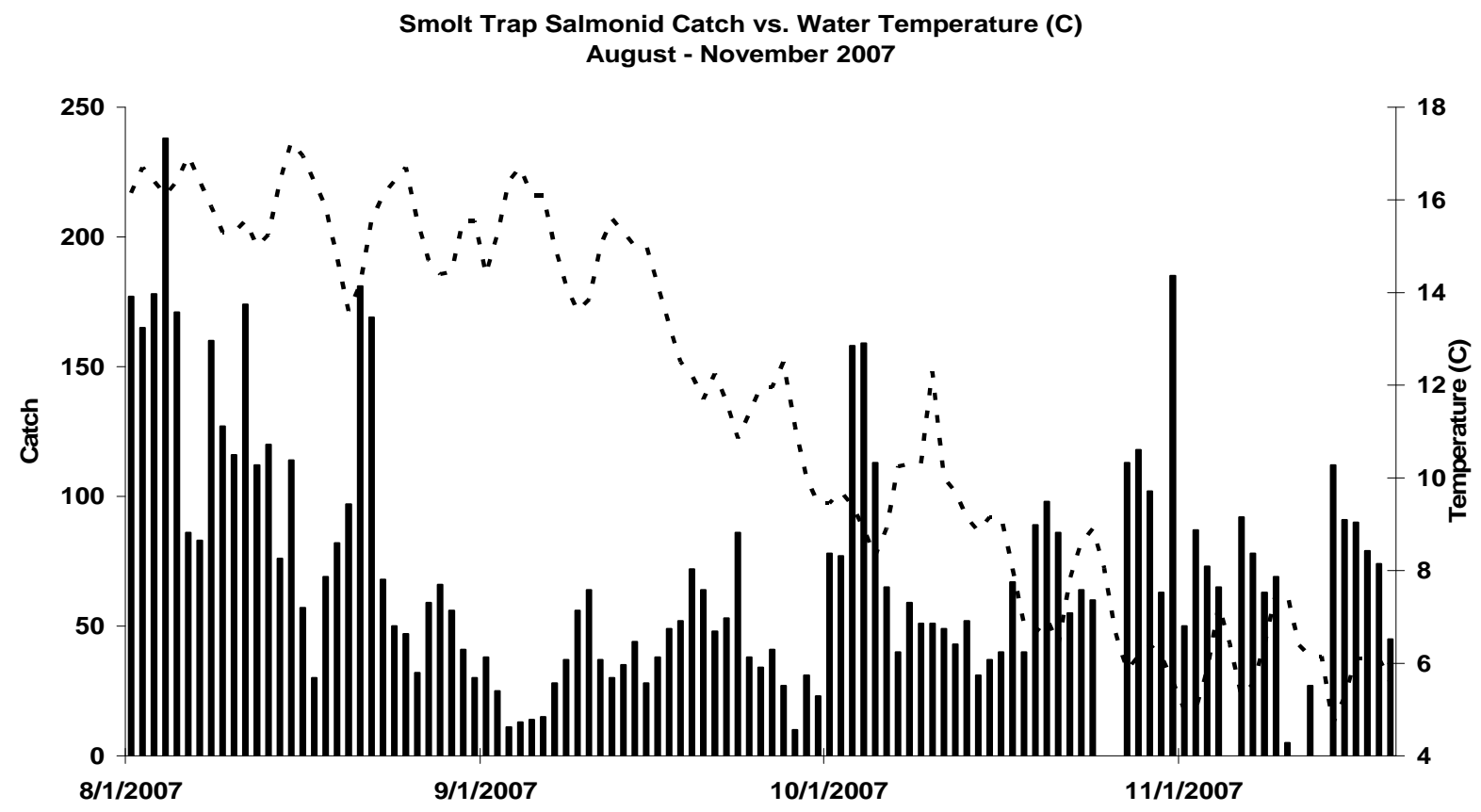

Figure 12. Juvenile salmonid rotary screw trap catch and daily average water temperature (dashed line) August through November 2007. 
Smolt Trap Salmonid Catch vs. Discharge (cfs)

August - November 2007

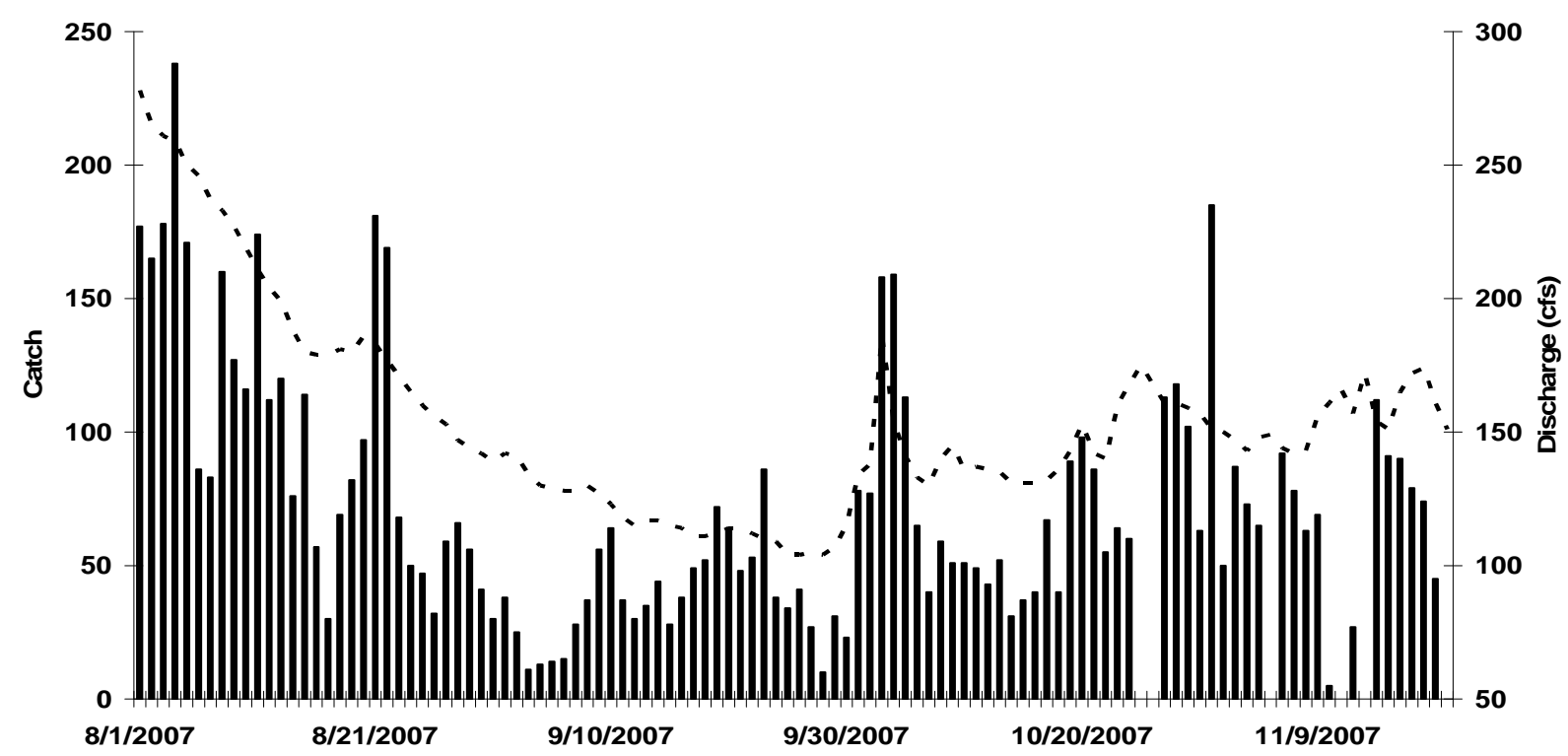

Figure 13. Juvenile salmonid rotary screw trap catch and daily discharge (dashed line) from the Entiat River August through November 2007.

\section{Trap efficiencies}

A total of 10 rotary screw trap efficiency trials were conducted during the study period.

The upper screw trap location had four suitable trials conducted with an average efficiency of $25.9 \%$ for Chinook and $11.0 \%$ for steelhead/rainbow. The lower trap efficiency was tested six times with an average efficiency of $18.7 \%$ for Chinook and 8.6\% for steelhead/rainbow. Discharge during the trial periods ranged from $263 \mathrm{cfs}$ to $130 \mathrm{cfs}$ with an average discharge at date of release of $189 \mathrm{cfs}$ (Table 7).

Table 7. Rotary screw trap efficiency trials August through November 2007. Wild Chinook denoted as CHN and steelhead/rainbow trout as SRT.

\begin{tabular}{cccc|cc|cc|cc|}
\hline & & & Trap & \multicolumn{2}{|c|}{ Released } & \multicolumn{2}{|c|}{ Recaptured } & \multicolumn{2}{|c|}{ Efficiency } \\
Date & Time & Discharge & Location & CHN & SRT & CHN & SRT & SRT & CHN \\
\hline $8 / 3 / 07$ & $19: 45$ & 262 & Upper & 168 & 16 & 32 & 0 & $0.0 \%$ & $19.0 \%$ \\
$8 / 7 / 07$ & $19: 25$ & 236 & Upper & 425 & 14 & 85 & 0 & $0.0 \%$ & $20.0 \%$ \\
$8 / 10 / 07$ & $20: 28$ & 214 & Upper & 353 & 25 & 85 & 1 & $4.0 \%$ & $24.1 \%$ \\
$8 / 10 / 07$ & $20: 36$ & 214 & Lower & 36 & 1 & 2 & 0 & $0.0 \%$ & $5.6 \%$ \\
$8 / 14 / 07$ & $20: 07$ & 182 & Upper & 145 & 21 & 41 & 5 & $23.8 \%$ & $28.3 \%$ \\
$8 / 14 / 07$ & $20: 23$ & 182 & Lower & 44 & 12 & 11 & 1 & $8.3 \%$ & $25.0 \%$ \\
$8 / 21 / 07$ & $19: 35$ & 183 & Upper & 157 & 32 & 60 & 9 & $28.1 \%$ & $38.2 \%$ \\
$10 / 4 / 07$ & $19: 05$ & 144 & Lower & 243 & 44 & 41 & 2 & $4.5 \%$ & $16.9 \%$ \\
$10 / 7 / 07$ & $17: 20$ & 130 & Lower & 132 & 23 & 23 & 0 & $0.0 \%$ & $17.4 \%$ \\
$10 / 31 / 07$ & $17: 20$ & 146 & Lower & 235 & 14 & 67 & 3 & $21.4 \%$ & $28.5 \%$ \\
Mean & & $\mathbf{1 8 9}$ & & $\mathbf{1 9 4}$ & $\mathbf{2 0}$ & $\mathbf{4 5}$ & $\mathbf{2}$ & $\mathbf{9 . 0 \%}$ & $\mathbf{2 2 . 3 \%}$ \\
\hline
\end{tabular}




\section{ATM/PTAGIS upload}

All data was uploaded into the Automated Template Module (ATM) for rotary screw trap smolt sampling on a bi-weekly basis throughout the season and completed on December 10, 2007. Individual PIT tag files were uploaded to the PTAGIS database weekly and were completed on December 10, 2007.

\section{Discussion-rotary screw trap}

\section{Rotary screw trap operation}

The day to day operation of rotary screw traps can pose some difficulty. The traps are at the mercy of the watershed at all times while suspended in the stream. Alterations in flow regime and/or weather events can cause debris to pile up on or in the smolt trap. To alleviate these potential hazards to the rotary screw traps, personnel and equipment, traps were pulled when necessary. During this study period, a total of 5 days were lost to poor flow regimes. Evening wind events in late October and November contributed to all 5 days of trapping lost. These weather events inundated screw trap live boxes with autumn leaves to the point the rotary cone would stop and sink. Modifications to the live box and debris drum system are currently in the design phase in order to sample on high debris load days. The USFWS will develop and implement a variable speed clutch system to increase the rotational speed of the debris drum during high flow/debris events. This system will also have the capability to decrease speed or disengage the debris drum in an effort to minimize the loss of emergent fry and lamprey larvae which are susceptible to riding out of the live box on the debris drum screen.

\section{Remote tagging operations}

During 2007, remote tagging operations were inhibited by water temperature thresholds of $17^{\circ} \mathrm{C}$ as listed in the ISEMP smolt trapping protocol (Nelle 2007). The Mad River proved to be a productive environment for angling. However, the most productive times of the day for fish feeding activity and angling success straddled the temperature boundary for any PIT tagging operation. Often times, remote tagging and angling events were shut down in the early afternoon when stream temperatures reached $16^{\circ} \mathrm{C}$ and capture rates remained high. This was required in order to ensure the fish we handled, captured and tagged were not exposed to temperatures outside of protocol. However, in our angling surveys, capture success was highest in temperature regimes from $12-16^{\circ} \mathrm{C}$ near the maximum allowable temperature of $17^{\circ} \mathrm{C}$. The remote tagging success for 2007 would have increased dramatically with a threshold around $20^{\circ} \mathrm{C}$. Days that were spent in the field remote tagging would not have been cut short, and partial days could have been added to the remote tagging schedule without violating protocols and/or permits (our current NOAA maximum permitted handling temperature is $21^{\circ} \mathrm{C}$ ). According to Wydoski and Whitney (2003), juvenile O. mykiss prefer water temperatures between 10$20^{\circ} \mathrm{C}$, but can tolerate temperatures between 0 and $26.7^{\circ} \mathrm{C}$. Similarly, juvenile $O$. tshawytscha prefer water temperatures of $15-18.5^{\circ} \mathrm{C}$. Lethal water temperature was listed as $22.7^{\circ} \mathrm{C}$ (Wydoski and Whitney 2003). These preferred temperatures are in the midrange of our currently allowed maximum temperature. It can be argued that a small increase to our tagging temperature threshold would improve remote tagging production 
in future seasons while maintaining fish health. This is worth future discussion. However, it must be stated that any increase in tagging temperature above $17^{\circ} \mathrm{C}$ would be in violation of the recommendations set forth in the PIT Tag Marking Procedures Manual (1999) as developed by the PIT Tag Steering Committee (PTSC) which has stated; "Because streamside marking is generally performed during the summer, water temperature is very important. Water temperatures in excess of 15 degrees Celsius cause stress and additional care must be taken when handling and tagging fish. Temperatures above 17 degrees Celsius cause severe stress and high mortality. The PTSC strongly recommends that all PIT tagging operations cease when water temperature exceeds 17 degree Celsius". To alleviate this issue, the USFWS will modify the remote tagging/capture schedule in 2008 to accommodate this threshold. Since fish handling can be sustained to above $20^{\circ} \mathrm{C}$ while adhering to sampling permits, capture and handling will be sustained even with temperature regimes above $17^{\circ} \mathrm{C}$, yet PIT tagging will cease. Furthermore, these fish will be held utilizing mid-channel flow through live boxes to be tagged the following day during adequate temperatures recommended by the PTSC.

\section{Summer vs. spring Chinook}

Early in the season, distinct morphological differences between summer sub-yearlings and spring Chinook yearlings make identification easy. Spring Chinook yearlings are much larger in size (100-150mm) in comparison to newly emergent summer Chinook fry (32-45 mm). This identification becomes much more difficult in late summer and early fall as sub-yearlings representing both the spring and summer Chinook out-migration life histories most likely overlap each other. Juvenile summer Chinook in the Entiat start their seaward migration in early summer and we believe finish up by autumn leaf fall. During this time it is likely that spring Chinook sub-yearlings can be found migrating as well. Currently, a definitive method to apportion these two runs of sub-yearlings is problematic and unverified. Our best effort to address this issue utilizes an estimation of population differences in out-migrant timing and fork length. In order to tease out the difference in migration timing, total catch was monitored and plotted by day. When catch dwindled and a relative nadir was reached in early September (Figure 12), all Chinook captured onward were delineated based on any detectable break in fork length distributions. Undoubtedly, some Chinook will be identified improperly using this method. However, this method has worked successfully for prior seasons and presents a management plan that can adapt to variations in run timing over many seasons. The implementation of a genetic sampling program in the latter part of the migratory season would help validate this method.

\section{Trap efficiencies}

The quantity of fish required for statistically sound trap efficiency trials proved to be a difficult task throughout the season. Several other trials were run during the study period, but were thrown out. Only trials with a minimum of 30 total tagged fished released were included in our analysis (Table 7). To improve our efficiency validity, PIT tagged fish were pooled from both traps for a maximum of 72 hours, and released as one efficiency trial. Similar modified trials will be adapted for future releases to improve upon trial success. 


\section{Project goals}

Project goals were met during the 2006-2007 field season. In order to evaluate the success of wild steelhead and spring Chinook, continued out-migrant monitoring is required. This is especially relevant, as the ENFH has discontinued the propagation of spring Chinook salmon as of 2007.

\section{Acknowledgements}

Many thanks go to the snorkelers from Mid-Columbia River Fisheries Resource Office, Leavenworth National Fish Hatchery, Yakama Nation and U.S. Forest Service. Additional thanks goes to the snorkeling support and shelter provided by Entiat National Fish Hatchery.

Many thanks to the smolt trap crew: Erica Saginus, Trevor Wilk, Heather Trainer, and Charles O. Hamstreet. Thank you to the WDFW remote tagging crew for the collaborative assistance in providing the snerding, the effective angling, and the sharing of invaluable information. Also, a big thank you to the short notice support provided by the additional MCFRO staff of Andy Johnsen, Drew Pearson, Ben Truscott, LeAnne Grove, Dave Carie, and Terry Dellapenna. And last but not least, this project would cease to exist without the support from Jason Reeves, Craig Eaton, and John Reir, the exceptional staff of Entiat National Fish Hatchery.

\section{References}

Chelan County Conservation District. 2004. Entiat Water Resource Inventory (WRIA) 46 Management Plan. October 2004. Prepared for the Entiat Watershed Planning Unit by the Chelan County Conservation District. Wenatchee, Washington.

Hillman, T. 2006. Monitoring Strategy for the Wenatchee River Basin. Draft Report. August 1, 2006. BioAnalysts, Inc. Pp. 76.

Mullan J. W., K. R. Williams, G. Rhodus, T. W. Hillman, J. McIntyre. 1992. Production and habitat of salmonids in the mid-Columbia River tributary streams. U.S. Fish and Wildlife Service Monograph I.

Nelle, P. 2007. Interim Protocols for the Capture, Handling, and Tagging of Wild Salmonids in the Upper Columbia Basin using Passive Integrated Transponder (PIT) Tags. Terraqua, Inc.

PIT Tag Marking Procedures Manual. v. 2.0. 1999. prepared by: Columbia Basin Fish and Wildlife Authority and the PIT Tag Steering Committee. Pp. 22 http://161.55.120.155/8.MPM.pdf.

Summerfelt, R.C. and L. S. Smith. 1990. Anesthesia, surgery, and related techniques. Pages 213-272 in C.S. Schreck and P.B. Moyle, editors. Methods for fish biology. American Fisheries Society, Bethesda, Maryland. 
Thurow, R.F. 1994. Underwater methods for study of salmonids in the Intermountain West. Gen. Tech. Report INT-GTR-307. USDA, Forest Service, Intermountain Research Station. Ogden, UT.

Wydoski R. S. and R. R. Whitney. 2003. Inland Fishes of Washington. American Fisheries Society University of Washington Press. 